\title{
Theorising ageing and the question of a long life: eye openings
}

\author{
By SIMON BIGGS*
}

\begin{abstract}
A life course perspective, drawing on historical and personal experiences, is used to identify eye-opening concepts that can be used to make sense of the world in terms of personal and social ageing, in the context of intergenerational relationships. Two issues have been identified that characterise a challenge to cultural adaptation: that of generations increasingly becoming approximately the same size as they move from demographic triangles to columns, and that of finding an age-specific purpose for a long life. An analysis of contemporary problems facing gerontology and social policy is given, drawing on the need for complementary life priorities and enhanced generational intelligence. Implications for work, generational rivalry and precarity are examined along with some conclusions on the role of eyeopening conceptual development.
\end{abstract}

Keywords: ageing, inequality, intergenerational, life course, precarity, psycho-social, work.

* Simon Biggs, School of Social and Political Science, University of Melbourne, Parkville, Australia 
International Journal of Ageing and Later Life

\section{Eye Openers and Personal History}

The first book that opened my eyes was by Young and Willmott (1957). It described working class life in Bethnal Green, in East London. It was a world that by the time I came across the work, had all but disappeared. But it spoke to me about something that I recognised. It made sense of the world. I could identify it. It was the world of my own grandparents, and it was the first time I came across a series of ideas that reflected my own common-sense experience back to me. In the mid-1970s, as a teenager, and as an English male, who considered himself more of a Londoner than a Brit, the heady days of hippydom were over, and the grim realities of recessional conflict were openly on the streets of Romford Market, where I worked a stall at the weekends. Given a choice between the recruiters of the National Front and the Hard Left, I chose the left. At about his time, my father, who had worked for London Transport's "Green Line" busses lost his job. He took another job, on lower pay and involving lesser skills, and hated it. By age 55, he was redundant again. He took early retirement to make way for the boomer generation, although we didn't have a name for them then. It turned out to be a blessing in disguise as he had 8 years to do what he wanted. He didn't live to draw his state pension although he had paid into it since the age of 14 , and on his death bed he said to me in a moment of exhausted astonishment: "but I have so much more to do." During this time, as Jung and De Beauvoir tell us, I never really thought about old age - it was a foreign country. I was immortal and there was a new world out there to get to grips with. What's more I had the manual, another eye-opener, and it was called the Communist Manifesto. Here was a book that not only explained the hidden workings of the social world but also told those with eyes to see, what to do about it. Even better, once you had read the manual, there was a whole army of follow-up books by the same author, and his followers, to explain in great detail how the whole thing functioned. But I found myself drawn to those parts that explained everyday experience to me: alienation, commodity fetishism, and the new and exciting world of the "personal being political." I was also reading the work of Erving Goffman (1961) on the management of self in everyday life and the writings of R.D. Laing (1961) on self and other. Goffman was a great character. I had met him when I was collecting lunch tickets (as a PhD student at Birkbeck College). He immediately started talking to me, 
of all people, asking me how I liked the conference, what were the interesting things I noticed. Maverick curiosity, however, did not enamour him to the rest of the lunch queue and my brief brush with genius was over. This was an eye-opener in a different way. Here was a real person, not simply the remote authority of words on a page or the podium, but a controlled eccentric who first experienced, then explained what he saw, in mental hospitals and identifying with the stigmatised, and wrote it up. It made me realise that writing and theorising were possible.

By the time I got my first "real job," I was working as a community psychologist in East London where my mother's family had lived. (Somewhere at home, I have a small box photo of my grandfather eating a sandwich while sitting on a steel girder overlooking what I think is Paddington station.) I had ended up with a strong sense of place and a positive sense of my grandparent's generation - as progressive politically, international in outlook, and as persons to love. But times were unlovely. Thatcher had come to power in the same week I got the post, and while it took a few years for the ugliness of her vision to emerge, the Thatcher-Regan alliance changed the world. To the one, the fruits of which we are still being forced to eat. After the defeat of the Miners in 1984-1985, like many, I turned inwards. Had started a family and realised I had to get real career wise. While my community psychology job was principally concerned with youth and young adulthood, working with older people had been a key part of the team's activity and led to a number of intergenerational projects under the tutelage of Mike Bender and Alison Cooper. They had been the first in the United Kingdom to take psychology out of the clinic and into social and community settings, and while the unit was short lived, their ideas had a profound influence on me. It may help explain why I have always been attracted to applied issues and theories and even now, am working with an agency whose strapline is "Working for an Australia without Poverty." To this day, I keep carrying a book around with me, Social Psychology and Social Relevance, written by Alan Elms in 1972. I got it second hand and as far as I can tell it has otherwise sunk without trace. But in terms of eye openings, it linked the academic to the practical and pointed out that these interconnections worked.

However, like many people drawn to academic work, I am not a natural extrovert, and while working in community psychology and undertaking 
International Journal of Ageing and Later Life

psychotherapy as an expected part of psycho-social practice, I became interested in the work of C. G. Jung. Jung's explanation of the indeterminacy of gendered identity, that the life course is marked by radical shifts in outlook and that each person has the capacity to develop those parts of themselves submerged by social conformity made sense. It explained, at least to me, how internal and external worlds connected and put the changes in priority that happen to people across the life course in conceptual perspective. Here was another tool, building on, but with much more flexibility, the stage theories of Erik Erikson that explained the ways that different age groups understood their worlds and the priorities they faced. By the time I arrived at the UK Social Work Agency (CCETSW) and picked up the brief on "the elderly" - the one that nobody else seemed to want - and even before I had encountered this thing called gerontology, certain concepts were already in place to interrogate the place of older people in society. A sense of social justice, an awareness of the tension between the social and the personal, and an interest in life course change and intergenerational identities, enhanced by a belief that ideas could change our worlds for better and for worse.

\section{Gerontology and Ideas}

All this may sound a rather odd way of starting a piece on theory as an eye-opener. In many ways, theories are a route out of being determined by events. They allow us to stand back and try and work out what is going on. And in this way they help us determine what to do about it, with whom and in what direction. They affect our interior as well as exterior worlds, the ways we think about our own ageing, our interaction with others and the factors that determine our life circumstances. They make sense of the world, the historical period we find ourselves thrown into and the stage of life we are grappling with, puzzled by and trying to understand.

There is a saying attributed to Bob Butler (Moody 1986), the author of Why Survive? and key player in the making of North American gerontology, that gerontology is an amalgam of science and advocacy. He was in part alluding to how closely gerontology followed current events and used its evidence base to promote the interests of older adults. Reading his 
Theorising ageing and the question of a long life

comments through Foucault, we now know that power and knowledge are never entirely separable, as politics influences which research is considered relevant and paid for, and it is often also a question of which voice is dominant and who is advocating for whom. For social gerontology, the relationship between social circumstances, policy and the expectations placed on us as we grow old has always been a vexed one and, as Caroll Estes et al. (2001) in the United States and Chris Phillipson (1998) in the United Kingdom have tirelessly reminded us, is contingent on structural inequalities that interact intimately with people's everyday lives. My background opened my eyes to political economy as an explanation of how injustice operates, but I was also interested in how people build protective arrangements to insulate themselves from negative events and to build bridges to the wider world.

So, while my own theoretical position has evolved over time, it has been based on a combination of psycho-social and political-economic concepts and wondering about the relationship between the two. For me, this crystallised around how personal experience interacted with developments in social policy and other less formal social discourses such as those associated with adult ageing and the life course. This process often became associated with barriers to self and collective expression such as social ageism and, in its most extreme form, elder abuse. It became clearer to me that the strategies people used to manage their everyday identities were closely connected to their experience of ageing in others and in themselves. Rather than being caught in a war with their own bodies (Featherstone \& Hepworth 1991), I saw the core contradiction being between a mature imagination that could not be expressed and social attitudes that shaped the legitimising forms of expression that were made available to them (Biggs 1999). This grew out of my reading of Jung, De Beauvoir and the gradual understanding that social ageism was a powerful, if at the time rarely acknowledged, means of perpetuating inequality and marginalisation of adult ageing. But how, I asked myself, did it operate in everyday life? Here the work of Judith Butler and Kathleen Woodward had an important effect, not so much that I read them deeply, but that they reopened my eyes to the way that people presented themselves and maintained threatened identities through a series of performances and masquerades. It resonated with Jung (who didn't like 
International Journal of Ageing and Later Life

personae, or the first half of life very much) and with Goffman's work on the presentation of self.

As mainstream social policy began to catch up with many of the proposals made by critical gerontology - for example, that age is not simply a matter of biological decline, no compulsory retirement age, the recognition of age discrimination and elder abuse as explicit social problems - it became clear that a new form of critique, paying greater attention to process rather than content was needed. The co-option and accompanying distortion of once radical concepts to justify the privatisation of social welfare and the erosion of pensions security, the requirement to work rather than the option of staying working, the increasing precarity that a new policy turn was bringing to ageing in mature economies, made it a priority to re-evaluate what a contemporary critical approach might be. Little by little, it seemed that the aims of a radical gerontology had been turned inside out. They had now become a means of legitimising the erosion of the conditions for a good life and to eclipse what was both problematic about and the special potential of a long life.

\section{Changed Priorities in Intergenerational Context}

All this required a re-examination of the processes that led older people to be both marginalised and devalued. The ground had changed, but the contradictions remained. At the interpersonal level, this showed itself as a lack of empathic understanding of the age-other, a tendency to perpetuate midlife priorities way beyond their shelf-life and a need for what Ariela Lowenstein and I came to call generational intelligence (2011). We both saw intergenerational relations as a great source of strength and of misunderstanding, which could easily become as Martin Kohli (2005) had suggested, a new field on which wider political and economic rivalries would be played out. Not that they are themselves a source of inequality, but as a cloak, covering deeper contradictions within society.

The continuities that had driven earlier critical thinking - staying in work, avoiding bodily ageing and social inclusion - appeared less and less satisfying, both intellectually and as a solution to changed economic and demographic circumstances. It appeared that the shifting sands of economics were not a secure enough material base on which to understand the 
Theorising ageing and the question of a long life

distinctive idiom of a long life. Discontinuity lay in the changing priorities suggested by different age-related projects and the existential questions that become increasingly pressing as one grows older, a sort of life course materiality. These are important if we are to discover the special contribution of a long life and critically examine the degree to which the self is in harmony with priorities that are life course specific.

In this context, a focus on age-specific life course priorities, arising from psycho-social thinking, appeared to be a more precise material base on which to build meaning and purpose than economic instrumentalism alone. It also set up an interesting way of recognising the complementary nature of generational difference. Yes, we do have different priorities as we grow up and age. We need to recognise rather than deny this and build of it a source of intergenerational strength, rather than competition and insecurity. The tension here is principally to do the boundaries that are set around age-otherness. When othering is combined with social ageism, it becomes a negative phenomenon (Phillips et al. 2010). However, recognition of otherness is also a key part in respecting the particular qualities of an age-specific experience and, in this sense, is the first step in not assuming that one's own position explains and supersedes the priorities of others. This it seemed to me, at least, provided a way of finding something special about ageing, an addition to critical gerontology and a move beyond "within age" thinking.

\section{Two Questions, Two Problems}

The combination of recognising that different age groups have different existential life priorities, that dominant groups tend to erase the perspectives of other ages and that this meant that intergenerational relations had to be consciously negotiated, set the scene for a new set of questions and the problems generated by new solutions. Furthermore, changing demographics raised the parallel question of the sort of cultural adaptation that was needed (Biggs 2014a). It seemed to me that we were facing two core questions. First, how do we adapt to a situation where generations will be of approximately the same size? That is to say that as societies change from traditional to mature economic structures, we will have moved from a demographic triangle with many children, whittled down to a few aged 
International Journal of Ageing and Later Life

survivors, to a column shape in which each generation consists of almost the same number of persons. Second, what is the purpose of a long life? Which is to pose the question, are there age-specific purposes, priorities and projects that arise from longevity itself?

Under contemporary circumstances, it appeared that two problems were rising as responses to demographic change: one reflects an international consensus on work as the solution to a long life and the other an emerging tension in the public domain around intergenerational relations.

\section{Work and a Long Life}

In terms of working longer, Thibauld Moulaert and I (2013) have claimed that this marks a shift from holistic to restricted policies of social inclusion, using the stick of reduced pension eligibility, backed up by productivist ideology. Alan Walker (2009) has expressed his frustration at the limited interpretation of active ageing, in terms of prolonged working life, that has come to dominate international policy. From the current perspective, work, as the solution to the question of a long life, has several disadvantages. First, it is unclear how far it fits with specific life course tasks, or whether it is simply "more of the same" and an extension of midlife projections onto a different phase of life. In other words, work may not allow the selfdevelopment promised by longevity, where there is so much more to do. Second, it is very much a "within later life" position. Although this solution addresses wider fiscal problems, in terms of generations, it does not really look beyond the presumed needs of older adult workers alone, which may form an answer for professional older adults, and doesn't readily place the extension of working life within the context of wider intergenerational processes and social inequalities. Third, work is assumed to be a relatively age-neutral and therefore power-neutral environment - while at the same time it is one's ability to compete, regardless of social categories, on the same ground of productivity - that determines social value. Finally, and perhaps most tellingly, work can be used as a means of avoiding the challenge of a long life. By relying on extrinsic work status, one is not forced to confront one's own intrinsic value that emerges as such props to identity are stripped away. 
Theorising ageing and the question of a long life

Work, then does not emerge as an adaptation to a longer life at all, rather it is simply a continuation of existing strategies. At root, it really is just more of the same, offering few opportunities for new and age-specific existential exploration.

\section{Intergenerational Relations}

In 2015, the Council for the Defence of Universities took out an advert to attract student votes for its policies. They made seven points. The fourth of which reads: "the current fees system shifts the entire funding burden from older people - whose university years cost them comparatively little or nothing - to the next generation." The Fairness Index of the Intergenerational Foundation (2015) between people under 30 and those over 60 highlight a sharply widening gap between generations. In Australia, the Grattan Institute (2014) had published a similar report, The Wealth of Generations, indicating that government policy should change public pension policy to reduce the benefits held by older generations to pay for the needs of other age groups. In fact, both reports cite the rising costs of housing, education and low wages as serious problems facing people in their twenties and thirties - none of which in themselves are generational issues. In both cases, a deterioration in the prospects of younger generations relative to older generations was seen to require a programme of "intergenerational rebalancing" also known as reduced support to older adults.

Putting aside the growing empirical evidence that younger adults appear neither to dislike nor see their elders as a burden (see Biggs 2014a for a brief review), the rivalry solution has a number of problems.

While generational rivalry recognises generational difference, it becomes stuck in a binary antagonism without rising to discover an encompassing intergenerational solution. No foundation on intergenerational relations then, but rather a fixation with a particular generational position and enhancing its advantage. Generational rivalry steps beyond the within-age horizon noted for "more of the same" solutions, but rather than attempting to resolve ambivalence around age-otherness, opts for conflict. In this sense, it would be an example of low generational intelligence - thinking that cannot take the position of the other into account. Furthermore, while it is 
International Journal of Ageing and Later Life

gerontologically commonplace to say that unlike other forms of difference, we all, with a bit of luck, move into the place of the age-other over time, this approach appears stuck in a form of present centredness. Learning from past experience rather than envious anticipation of something that has not yet happened redirects energy to considering how the advantages of previous generations may be re-built and regained from a longitudinal and life course perspective. Competition between generations is essentially fruitless at a macro-temporal level, as one is eventually competing against one's own future.

There is, however, another way of seeing intergenerational relations, as a simultaneous experiencing of the erosion of current and future life chances. Both are becoming more precarious. Guy Standing (2011) has argued that the processes of increasing globalisation have created precarity in everyday life, marked by job insecurity, discontinuity of identity and lack of time control. These, he argues, would include young adults who may well have an education but find themselves in work that has little security, poor pay and no obvious career pathway. There are certainly indications that a long life is also becoming a precarious one, including information in The International Labour Organisation's World Social Protection Report 2014/15 (2015) and the Australian BSL Social Exclusion Monitor (2014). The likelihood of an increasingly precarious ageing would be exacerbated by lengthened statutory retirement ages, questions over availability and forms of work, plus inadequate and unaffordable care and support services (Biggs 2014b). Precarity forms a common site for generational solidarity now, and for all our futures. Perhaps, it can open our eyes, also, to the common yet complementary interests of generations and the possibility for self-conscious social change.

\section{Eye Openers: Some Concluding Comments}

In terms of theory, then, it would be wrong of me to say this or that theory was in itself an eye-opener. Rather, conceptual development emerged through a happy discovery of theories that explain the world and personal experience in a way that helped make sense of it and suggest alternatives. A further conceptual leap is to work out how such concepts can be applied to persons with very different experiences, such as those 
Theorising ageing and the question of a long life

associated with age. And in that sense, it consists of an amalgam of personal experience, empathic ability and historical circumstance. Once you have worked out your theory, you can apply it to interrogate all sorts of conundra. When it ceases to make sense, you can see if there is some way of rethinking what's been going on to start the concepts moving again.

\section{Corresponding Author}

Simon Biggs, School of Social and Political Science, John Medley Building, University of Melbourne, Parkville 3010 VIC, Australia. Email: biggss@ unimelb.edu.au

\section{References}

Biggs, S. (1999). The Mature Imagination: Dynamics of Identity in Midlife and Beyond. Maidenhead: Open University Press.

Biggs, S. (2014a). Adapting to an ageing society: The need for cultural change. Policy Quarterly 10(23): 12-17.

Biggs, S. (2014b). Precarious ageing versus the policy of indifference: International trends and the G20. Australasian Journal of Gerontology 33(4): 226-229.

Biggs, S. \& Lowenstein, A. (2011). Generational Intelligence: A Critical Approach to Age Relations. London: Routledge.

Brotherhood of St Laurence. (2014). Social Exclusion Monitor. Available on http://www.bsl.org.au/research-and-publications/social-exclusionmonitor/ (Accessed: August 21, 2015).

Council for the Defence of Universities. (2015). Advertisement. London Review of Books, 7 May.

Elms, A. (1972). Social Psychology and Social Relevance. Boston, MA: Little Brown.

Estes, C. L., Linkins, K. \& Binney, E. (2001). Critical Perspectives on Aging: The Political and Moral Economy of Growing Old. New York, NY: Baywood.

Featherstone, M. \& Hepworth, M. (1991). The mask of ageing and the postmodern lifecourse. In M. Featherstone, M. Hepworth, \& B. Turner (eds.), The Body, Social Process and Cultural Theory (pp. 143-157). London: Sage. 
International Journal of Ageing and Later Life

Goffman, E. (1961). The Presentation of Self in Everyday Life. London: Penguin.

Grattan Institute. (2014). The Wealth of Generations. Available on http:// grattan.edu.au/report/the-wealth-of-generations/ (Accessed: August $23,2015)$.

Intergenerational Foundation. (2015). Intergenerational Fairness Index. Available on http://www.if.org.uk/archives/6909/2015-intergenerationalfairness-index (Accessed: August 26, 2015).

International Labour Organisation. (2015). World Social Protection Report 2014/15. Available on http://www.ilo.org/global/research/global-reports/ world-social-security-report/2014/lang--en/index.htm (Accessed: August 23, 2015).

Kohli, M. (2005). Generational changes and generational equity. In M. L. Johnson, V. L. Bengtson, P. G. Coleman \& T. B. L. Kirkwood (eds.), The Cambridge Handbook of Age and Ageing (pp. 518-526). Cambridge: Cambridge University Press.

Laing, R. D. (1961). Self and Other. London: Tavistock.

Moody, H. (1986). The meaning of life and the meaning of old age. In T. Cole \& S. Gaddow (eds.), What Does It Mean to Grow Old? (pp. 9-41). Durham, NC: Duke University Press.

Moulaert, T. \& Biggs, S. (2013). International and European policy on work and retirement: Reinventing critical perspectives on active ageing and mature subjectivity. Human Relations 66(1): 23-43.

Phillips, J., Ajrouch, K. \& Hillcoat-Nalletamby, S. (2010). Key Concepts in Social Gerontology. London: Sage.

Phillipson, C. (1998). Reconstructing Old Age. London: Sage.

Standing, G. (2011). The Precariat: The New Dangerous Class. London: Bloomsbury.

Young, M. \& Willmott, P. (1957). Family and Kinship in East London. London: Penguin.

Walker, A. (2009). Commentary: The emergence and application of active aging in Europe. Journal of Aging \& Social Policy 21(1): 75-93. 